Penerapan Model Pembelajaran ....(Hana Rustina)

\title{
PENERAPAN MODEL PEMBELAJARAN METODE DEMONTRASI \\ DALAM MENINGKATKAN HASIL BELAJAR IPA SISWA SD NEGERI 65 PALEMBANG
}

\author{
Oleh: Hana Rustina \\ Email: rustina_h@gmail.com \\ (Guru SD Negeri 65 Palembang)
}

\begin{abstract}
Abstrak
Tujuan penelitian tindakan ini untuk mengetahui peningkatan hasil belajar siswa pada mata pelajaran IPA melalui model pembelajaran Metode Demontrasi SD Negeri 65 Palembang. Subjek dalam penelitian ini berjumlah 27 orang siswa. Penelitian ini menggunakan penelitian tindakan kelas yang dilakukan sebanyak dua putaran. Setiap putaran terdiri dari empat tahap yaitu: rancangan, kegiatan dan pengamatan, refleksi, dan revisi. Data yang diperoleh berupa hasil tes formatif, lembar observasi kegiatan belajar mengajar. Dari hasil analis data diperoleh bahwa hasil belajar siswa mengalami peningkatan yang signifikan. peningkatan hasil belajar tersebut ditandai dengan peningkatan ketuntasan belajar siswa dalam setiap siklusnya, yaitu pra siklus mencapai 33.33\%, siklus I meningkat sebesar 70.37\%, dan siklus II mengalami peningkatan yang sangat baik mencapai 85,19\%. Dari hasil analisis data diperoleh dapat disimpulkan bahwa model pembelajaran Metode Demontrasi dapat berpengaruh positif terhadap peningkatan hasil belajar siswa kelas II SD Negeri 65 Palembang.
\end{abstract}

Kata Kunci: Hasil Belajar IPA, Metode Demontrasi

\section{APPLICATION OF DEMONTRATION METHOD LEARNING MODELS IN IMPROVING THE SCIENCE LEARNING OUTCOMES STUDENTS. SD NEGERI 65 PALEMBANG}

\begin{abstract}
The purpose of this action research is to determine the increase in student learning outcomes in science subjects through the demonstration method learning model SD Negeri 65 Palembang. The subjects in this study amounted to 27 students. This research uses classroom action research which is conducted in two rounds. Each round consists of four stages, namely: design, activities and observations, reflection, and revision. The data obtained are in the form of formative test results, observation sheets of teaching and learning activities. From the results of the data analysis, it was found that student learning outcomes had increased significantly. The increase in learning outcomes was marked by an increase in student learning completeness in each cycle, namely pre-cycle reaching $33.33 \%$, cycle I increased by $70.37 \%$, and cycle II experienced a very good increase reaching $85.19 \%$. From the results of data analysis, it can be concluded that the demonstration method learning model can have a positive effect on increasing the activity and learning outcomes of class II SD Negeri 65 Palembang
\end{abstract}


Wahana Didaktika Vol. 19 No.1 Januari 2021 : 81-91

Keywords: Learning Outcomes Science, Demonstration Methods.

\section{A. PENDAHULUAN}

Tujuan utama pembelajaran Ilmu Pengetahuan Alam (IPA) adalah agar siswa memahami konsep-konsep IPA secara sederhana dan mampu menggunakan metode ilmiah, bersikap ilmiah untuk memecahkan masalah-masalah yang dihadapi dengan lebih menyadari kebesaran dan kekuasaan pencipta alam (Depdikbud, 1997, p.2). Pembelajaran IPA memiliki fungsi yang fundamental dalam menimbulkan serta mengembangkan kemampuan berpikir kritis, kreatif dan inovatif. Agar tujuan tersebut dapat tercapai, maka IPA perlu diajarkan dengan cara yang tepat dan dapat melibatkan siswa secara aktif yaitu melalui proses dan sikap ilmiah.

Dalam rangka menigkatkan kualitas pendidikan di lingkungan sekolah diperlukan beragam strategi pembelajaran inovatif yang diharapkan mampu memperbaiki proses pembelajaran yang telah berlangsung. Salah satu tolak ukur keberhasilan guru adalah bila dalam pembelajaran mencapai hasil yang optimal. Keberhasilan ini sangat tergantung dengan kemampuan guru dalam mengelola proses belajar mengajar. Keberhasilan pembelajaran pada umumnya adalah meningkatnya hasil belajar siswa . Pada dasarnya pemahaman konsep pada siswa kelas II SD masih cukup rendah. Terutama jika pembelajaran yang disampaikan guru tidak menarik minat dan motivasi anak dalam belajar. Hal ini tentunya akan berdampak pada tinggi rendahnya hasil belajar yang diperoleh siswa .

Pada kenyataannya, hasil belajar yang diperoleh siswa kelas II.B SD Negeri 65 Palembang, salah satunya pada pelajaran Ilmu Pengetahuan Alam (IPA) masih menunjukkan nilai yang rendah. Jika dilihat dari hasil ulangan harian sebagian besar siswa masih memperoleh hasil belajar di bawah Kriteria Ketuntasan Minimal (KKM) yang telah ditetapkan yaitu sebesar 70. Dari 27 siswa hanya 9 siswa atau $33.33 \%$ yang sudah memenuhi KKM, sedangkan 18 siswa atau $66.67 \%$ belum berhasil memenuhi KKM.

Hal tersebut, diperkirakan karena kurangnya pemahaman siswa terhadap konsep pembelajaran IPA. Mereka menganggap pelajaran IPA sulit dipahami. 
Untuk anak-anak yang taraf berpikirnya masih berada pada tingkat konkret, maka semua yang diamati, diraba, dicium, dilihat, didengar, dan dikecap akan kurang berkesan kalau sesuatu itu hanya diceritakan, karena mereka belum dapat menyerap hal yang bersifat abstrak. Perlu diketahui bahwa tingkat pemahaman tiap-tiap siswa tidak sama, sehingga kecepatan siswa dalam mencerna bahan pengajaran berbeda.

Faktor yang paling berpengaruh adalah faktor guru, yakni metode yang digunakan guru dalam melaksanakan pembelajaran. Oleh karena itu guru perlu mempersiapkan dan merencanakan pembelajaran dengan sebaik-baiknya agar dapat diciptakan kegiatan belajar mengajar yang aktif, kreatif, inovatif, dan menyenangkan, sehingga dapat mencapai tujuan pembelajaran yang diharapkan.

Penyampaian materi pelajaran IPA perlu dirancang suatu strategi pembelajaran yang tepat, yakni anak akan mendapatkan pengalaman baru dalam belajarnya, selain itu siswa akan merasa nyaman. Strategi pembelajaran IPA harus dirancang sedemikian rupa dengan mempertimbangkan kemajuan Ilmu Pengetahuan dan Teknologi di samping harus bertumpu pada pengalaman indera menuju terbentuknya pengalaman kesimpulan yang logis.

Salah satu model pembelajaran yang dapat membantu guru mencapai tujuan pembelajaran adalah metode demontrasi. Metode demonstrasi adalah metode yang digunakan untuk memperlihatkan sesuatu proses atau cara kerja suatu benda yang berkenaan dengan bahan pelajaran (Djamarah, 2000).

Demonstrasi merupakan metode yang sangat efektif, sebab membantu siswa untuk mencari jawaban dengan usaha sendiri berdasarkan fakta atau data yang benar. Metode demonstrasi merupakan metode penyajian pelajaran dengan memperagakan dan mempertunjukkan kepada siswa tentang suatu proses, situasi atau benda tertentu, baik sebenarnya atau hanya sekadar tiruan. Sebagai metode penyajian, demonstrasi tidak terlepas dari penjelasan secara lisan oleh guru. Walaupun dalam proses demonstrasi peran siswa hanya sekadar memerhatikan, akan tetapi demonstrasi dapat menyajikan bahan pelajaran lebih konkret. Dalam strategi pembelajaran, demonstrasi dapat digunakan untuk mendukung keberhasilan strategi pembelajaran. 
Wahana Didaktika Vol. 19 No.1 Januari 2021 : 81-91

Seperti yang telah diutarakan di atas pada saat pembelajaran IPA disebutkan bahwa fungsi metode mengajar dalam keseluruhan system pengajaran adalah sebagaimana alat untuk mencapai tujuan pengajaran. Metode Demontrasi sebagai salah satu alternatif dalam pembelajaran IPA yang membawa siswa belajar dalam suasana yang lebih nyaman dan menyenangkan. Berdasarkan latar belakang yang telah dikemukakan diatas, maka peneliti merumuskan permasalahan sebagai berikut, apakah model pembelajaran Metode Demontrasi dapat meningkatkan hasil belajar IPA pada siswa kelas II SD Negeri 65 Palembang.

Pembelajaran kooperatif adalah sebuah kelompok strategi pengajaran yang melibatkan siswa bekerja secara berkolaborasi untuk mencapai tujuan bersama. Untuk mencapai hasil yang maksimal dalam dunia pendidikan, saat ini berkembang berbagai model pembelajaran. Secara harfiah model pembelajaran merupakan strategi yang digunakan guru untuk meningkatkan motivasi belajar, sikap belajar di kalangan siswa , mampu berpikir kritis, keterampilan sosial, dan hasil pembelajaran yang optimal (Isjoni, 2009, p.7-8). Menurut Rusman (2012, p.202) Pembelajaran kooperatif (cooperative learning) merupakan bentuk pembelajaran dengan cara siswa belajar dan bekerja dalam kelompok-kelompok kecil secara kolaboratif yang anggotanya terdiri dari empat sampai enam orang dengan struktur kelompok yang bersifat heterogen.

Menurut Sanjaya (2006, p.152) metode demonstrasi "Metode penyajian pelajaran dengan memperagakan dan mempertunjukan kepada siswa tentang suatu proses, situasi atau benda tertentu, baik sebenarnya atau hanya sekadar tiruan." Sebagai metode penyajian, demonstrasi tidak terlepas dari penjelasan secara lisan oleh guru. Walaupun dalam proses demonstrasi peran siswa hanya sekedar memperhatikan, akan tetapi demonstrasi dapat menyajikan bahan pelajaran lebih konkret dalam setrategi pembelajaran ekspositori dan inkuiri.

Daryanto (2009, p.403) mengatakan bahwa metode demonstrasi "cara penyajian bahan pelajaran dengan meragakan atau mempertunjukan kepada siswa suatu proses situasi, atau benda tertentu yang sedang dipelajari, baik sebenarnya ataupun tiruan yang sering disertai penjelasan Iisan.” 
"Belajar adalah suatu aktivitas atau suatu proses untuk memperoleh penngetahuan, meningkatkan keterampilan memperbaiki perilaku/ siakap dan mengkokohkan kepribadian" (Hariyanto, 2012, p.19). Selanjutnya Hariyanto (2012, p.19) mengemukakan bahwa belajar merupakan suatu aktivitas atau suatu proses memperoleh pengetahuan, meningkatkan keterampilan, memperbaiki perilaku sikap dan mengkokohkan kepribadian.

Menurut Piaget (dalam Sagala, 2010, p.29) belajar mengandung makna sebagai perubahan struktural yang saling melengkapi antara asimilasi dan akomodasi dalam proses menyusun kembali dan mengubah apa yang telah diketahui melalui belajar. Jika seseorang belajar sesuatu sebagai hasilnya ia akan mengalami perubahan tingkah laku secara menyeluruh dalam sikap, keterampilan, pengetahuan, dan sebagainya. Misalnya orang yang tadinya tidak tahu setelah mengalami proses belajar maka akan menjadi tahu. Dapat dikatakan terjadi proses belajar, apabila seseorang menunjukkan tingkah laku yang berbeda.

Hasil belajar adalah suatu angka indeks yang dicapai oleh siswa melalui proses belajar yang bersifat individual, saat proses belajar terjadi dalam diri individu sesuai dengan perkembangan dan pengaruh lingkungannya. Keberhasilan dan ketidak berhasilan dalam belajar siswa dipengaruhi oleh banyak faktor, seperti yang dikemukakan Slameto bahwa:" Faktor-faktor yang mempengaruhi belajar adalah kesehatan, intelegensi, kesiapan, cacat tubuh, minat, bakat, motivasi, kematangan, kelelahan, keluarga, sekolah dan masyarakat". (Slameto, 2003, p.54)

Menurut Abdurrahman (2009, p.37) "Hasil belajar adalah kemampuan yang diperoleh anak setelah melalui kegiatan belajar". Hasil belajar tampak sebagai terjadinya perubahan tingkah laku pada diri siswa yang dapat diamati dan diukur dalam perubahan pengetahuan sikap dan keterampilan. Perubahan dapat diartikan terjadinya peningkatan dan pengembangan yang lebih baik dibandingkan dengan sebelumnya, misalnya dari tidak tahu menjadi tahu, sikap tidak sopan menjadi sopan dan sebagainya (Hamalik, 2012, p.155).

Menurut Kurikulum Pendidikan Dasar dalam Garis-garis Besar Program Pendidikan (GBPP) kelas V Sekolah Dasar dinyatakan: Ilmu Pengetahuan Alam 
Wahana Didaktika Vol. 19 No.1 Januari 2021 : 81-91

(IPA) atau sains merupakan hasil kegiatan manusia yang berupa pengetahuan, gagasan dan konsep-konsep yang terorganisasi tentang alam sekitar, yang diperoleh dari pengalaman melalui serangkaian proses kegiatan ilmiah antara lain penyelidikan, penyusunan dan pengujian gagasan-gagasan.

\section{B. METODOLOGI PENELITIAN}

Penelitian ini menggunakan penelitian tindakan kelas. Istilah dalam bahasa Inggris adalah Classroom Action Research (CAR), yaitu sebuah kegiatan penelitian yang dilakukan di kelas. Kemmis dan Taggart dalam Kasbolah (1999, p.13) mengemukakan bahwa "penelitian tindakan merupakan suatu bentuk penelitian yang bersifat reflektif yang dilakukan oleh pelaku dalam masyarakat sosial dan bertujuan untuk memperbaiki pekerjaannya, memahami pekerjaan ini serta situasi dimana pekerjaan ini dilakukan".

Tim Pelatih Proyek PGSM (Depdikbud, 1997, p.3) memberikan pengertian penelitian tindakan sebagai berikut; Penelitian tindakan adalah suatu bentuk kajian yang bersifat reflektifm oleh pelaku tindakan, yang dilakukan untuk meningkatkan kemantapan rasional dari tindakan-tindakan mereka dalam melaksanakan tugas, memperdalam pemahaman terhadap tindakan-tindakan yang dilakukannya serta memperbaiki kondisi dimana praktek pembelajaran tersebut dilakukan.

Tempat penelitian adalah tempat yang digunakan dalam melakukan penelitian untuk memperoleh data yang diinginkan. Penelitian ini bertempat di SD Negeri 65 Palembang. Waktu penelitian adalah waktu berlangsungnya penelitian atau saat penelitian ini dilangsungkan. Penelitian ini dilaksanakan pada bulan Agustus 2016 sampai Oktober semester ganjil tahun pelajaran 2016/2017.

Subjek penelitian adalah siswa-siswi kelas II.B SD Negeri 65 Palembang dengan jumlah siswa 27 orang. Dan pokok bahasan IPA yang disampaikan sesuai dengan kompetensi dasar, yaitu "Mengenal bagian-bagian utama tubuh hewan dan tumbuhan, pertumbuhan hewan dan tumbuhan serta berbagai tempat hidup makhluk hidup". Dalam penelitian ini keberhasilan dilihat dari hasil tes dalam setiap siklus. 
Dalam penentuan ketuntasan siswa, peneliti berpedoman pada Kriteria Ketuntasan Minimal (KKM) yang ditetapkan di SD Negeri 65 Palembang untuk mata pelajaran IPA, yaitu 70 dan keberhasilan penelitian ini dapat dilihat jika secara klasikal jumlah siswa yang memperoleh nilai minimal 70 telah mencapai 85\% dari jumlah keseluruhan siswa. Sesuai dengan jenis penelitian yang dipilih, yaitu penelitian tindakan. Setiap siklus meliputi planning (rencana), action (tindakan), observation (pengamatan), dan reflection (refleksi). Langkah pada siklus berikutnya adalah perencanaan yang sudah direvisi, tindakan, pengamatan, dan refleksi.

\section{HASIL PENELITIAN DAN PEMBAHASAN}

\section{Siklus I}

Pelaksanaan kegiatan belajar mengajar untuk siklus I dilaksanakan dalam 2 kali pertemuan. Pertemuan pertama tanggal 29 Agustus 2016 dan pertemuan kedua pada tanggal 1 september 2016 di kelas II-B dengan jumlah 27 orang. Pada setiap pertemuan terdapat 3 tahapan yaitu kegiatan pendahuluan, kegiatan inti, kegiatan penutup. Setiap kegiatan per siklus akan di amati seorang observer yang bertugas mencatat semua kegiatan yang terjadi selama proses pembelajaran. Adapun proses belajar mengajar mengacu pada rencana pelajaran yang telah dipersiapkan. Adapun tahapan siklus I sebagai berikut;

Guru mengisi daftar hadir kelas dan memulai dengan berdoa. Mempersiapkan materi ajardan model pembelajaran. Kemudian guru menyiapkan alat peraga. Memperingatkan cara duduk yang baik. Guru sebelum memulai persiapkanlah sekali lagi kesiapan peralatan yang akan didemonstarsikan, pengaturan tempat, keterangan tentang garis besar langkah dan pokok-pokok yang akan didemonstrasikan.

Guru memulai langkah demontrasi dengan menarik perhatian siswa. Guru mengingatkan pokok materi materi agar demontrasi cepat sasaran. Guru memperhatikan keadaan siswa. Guru menciptakan suasanan yang tenang Guru memberikan kesempatan kepada siswa untuk aktif dalam proses pembelajaran. Siswa dan guru bertanya jawab tentang materi yang telah dipelajari dalam 
pertemuan itu untuk mengetahui pencapaian indikator pencapaian kompetensi dan kompetensi dasar. Siswa dan guru membuat kesimpulan tentang materi yang telah dipelajari. Siswa dan guru berdoa sesuai dengan agama dan kepercayaan masingmasing.

Pelaksanaan observasi dilakukan selama peneliti melaksanakan kegiatan proses belajar mengajar. Adapun yang diamati oleh pengamat meliputi aktivitas siswa selama proses pembelajaran. Selain itu, pada setiap akhir proses belajar mengajar siswa akan diberikan tes, dengan tujuan untuk mengukur sejauh mana tingkat keberhasilan peneliti dalam melaksanakan proses pembelajaran.

Berikut hasil tes pada siklus I, yang dinyatakan dalam tabel berikut ini.

Tabel 1 Hasil Belajar Siklus I

\begin{tabular}{|c|l|c|}
\hline No & \multicolumn{1}{|c|}{ INDIKATOR } & KET \\
\hline 1 & Nilai rata-rata & 70.19 \\
\hline 2 & Banyaknya siswa Tuntas & 19 \\
\hline 3 & Persentase siswa yang Tuntas & 70.37 \\
\hline
\end{tabular}

Berdasarkan uraian tabel di atas, hasil tes siklus I memperoleh nilai rata rata 70,19 pada siklus I terdapat 19 siswa yang tuntas yakni sebesar $70.37 \%$ dari 27 siswa yang mengikuti proses pembelajaran. Kemudian siswa yang belum mendapatkan nilai yang belum tuntas atau belum melewati KKM (70) adalah 8 siswa dengan persentase 29,62\%. Jadi disimpulkan bahwa hasil ketuntasan secara keseluruhan belum melewati target KKM klasikal sebesar 85\%, pada siklus siklus I hanya mendapatkan persentase 70,37 yang masih rendah dari target ketuntasan KKM (85).

Beberapa kelemahan yang ditemukan pada siklus I ini adalah: Guru terlalu cepat dalam menyampaikan materi dengan model Demontrasi. Siswa belum menjalankan proses pembelajaran dengan baik karena masih banyak yang mengobrol dengan kawan yang lain. Siswa masih banyak yang keluar masuk kelas saat proses pembelajaran berlangsung.

\section{Siklus II}

Pelaksanaan kegiatan belajar mengajar untuk siklus I dilaksanakan dalam 2 kali pertemuan. Pertemuan pertama tanggal 5 September 2016 dan pertemuan kedua pada tanggal 8 september 2016 di kelas II-B dengan jumlah 27 orang. Pada 
setiap pertemuan terdapat 3 tahapan yaitu kegiatan pendahuluan, kegiatan inti, kegiatan penutup. Setiap kegiatan per siklus akan di amati seorang observer yang bertugas mencatat semua kegiatan yang terjadi selama proses pembelajaran. Adapun proses belajar mengajar mengacu pada rencana pelajaran yang telah dipersiapkan. Adapun tahapan siklus II sebagai berikut;

Guru sebelum memulai persiapkanlah sekali lagi kesiapan peralatan yang akan didemonstarsikan, pengaturan tempat,keterangan tentang garis besar langkah dan pokok-pokok yang akan didemonstrasikan. Guru memulai langkah demontrasi dengan menarik perhatian siswa. Guru mengingatkan pokok materi materi agar demontrasi cepat sasaran. Guru memperhatikan keadaan siswa .Guru menciptakan suasanan yang tenang. Guru memberikan kesempatan kepada siswa untuk aktif dalam proses pembelajaran. Siswa dan guru bertanya jawab tentang materi yang telah dipelajari dalam pertemuan itu untuk mengetahui pencapaian indikator pencapaian kompetensi dan kompetensi dasar. Siswa dan guru membuat kesimpulan tentang materi yang telah dipelajari. Siswa dan guru berdoa sesuai dengan agama dan kepercayaan masing-masing.

Pelaksanaan observasi dilakukan selama peneliti melaksanakan kegiatan proses belajar mengajar. Adapun yang diamati oleh pengamat meliputi aktivitas siswa selama proses pembelajaran. Selain itu, pada setiap akhir proses belajar mengajar siswa akan diberikan tes, dengan tujuan untuk mengukur sejauh mana tingkat keberhasilan peneliti dalam melaksanakan proses pembelajaran.

Berikut hasil tes pada siklus II, yang dinyatakan dalam tabel berikut ini.

Tabel 2 Hasil Belajar Siklus II

\begin{tabular}{|c|l|c|}
\hline No & \multicolumn{1}{|c|}{ INDIKATOR } & KET \\
\hline 1 & Nilai rata-rata & 73.33 \\
\hline 2 & Banyaknya siswa Tuntas & 23 \\
\hline 3 & Persentase siswa yang Tuntas & 85,19 \\
\hline
\end{tabular}

Berdasarkan uraian tabel di atas, hasil tes siklus II memperoleh nilai rata rata 73.33 pada siklus I terdapat 23 siswa yang tuntas yakni sebesar 85,19\% dari 27 siswa yang mengikuti proses pembelajaran. Kemudian siswa yang belum mendapatkan nilai yang belum tuntas atau belum melewati KKM (70) adalah 4 siswa dengan persentase $14,81 \%$. Jadi disimpulkan bahwa hasil ketuntasan secara 
Wahana Didaktika Vol. 19 No.1 Januari 2021 : 81-91

keseluruhan sudah melewati target KKM klasikal sebesar 85\%, pada siklus II mendapatkan persentase 85,19 yang sudah melewati target ketuntasan KKM (85).

Selama proses belajar mengajar guru telah melaksanakan semua pembelajaran dengan baik. Meskipun ada beberapa aspek yang belum sempurna, tetapi persentase pelaksanaannya untuk masing-masing aspek cukup besar. Berdasarkan data hasil pengamatan diketahui bahwa siswa aktif selama proses belajar berlangsung. Kekurangan pada siklus-siklus sebelumnya sudah mengalami perbaikan dan peningkatan sehingga menjadi lebih baik.

Pada siklus II guru telah menerapkan metode Demontrasi dengan baik dan dilihat dari hasil belajar siswa pelaksanaan proses belajar mengajar sudah berjalan dengan baik. Maka tidak diperlukan Refisi terlalu banyak, tetapi yang perlu diperhatikan untuk tindakan selanjutnya adalah memaksimalkan dan mempertahankan apa yang telah ada dengan tujuan agar pada pelaksanaan proses belajar mengajar selanjutnya penerapan metode Demontrasi dapat meningkatkan proses belajar mengajar sehingga tujuan pembelajaran dapat tercapai.

\section{PEMBAHASAN}

Melalui hasil peneilitian ini menunjukkan bahwa metode demontrasi memiliki dampak positif dalam meningkatkan hasil belajar siswa. Hal ini dapat dilihat dari semakin mantapnya pemahaman siswa terhadap materi yang disampaikan guru (ketuntasan belajar meningkat dari prasiklus, I dan II) yaitu masing-masing 33,33\%; 70,73\%; 85,19\%. Pada siklus II ketuntasan belajar siswa secara klasikal telah tercapai seperti gambar di bawah ini:

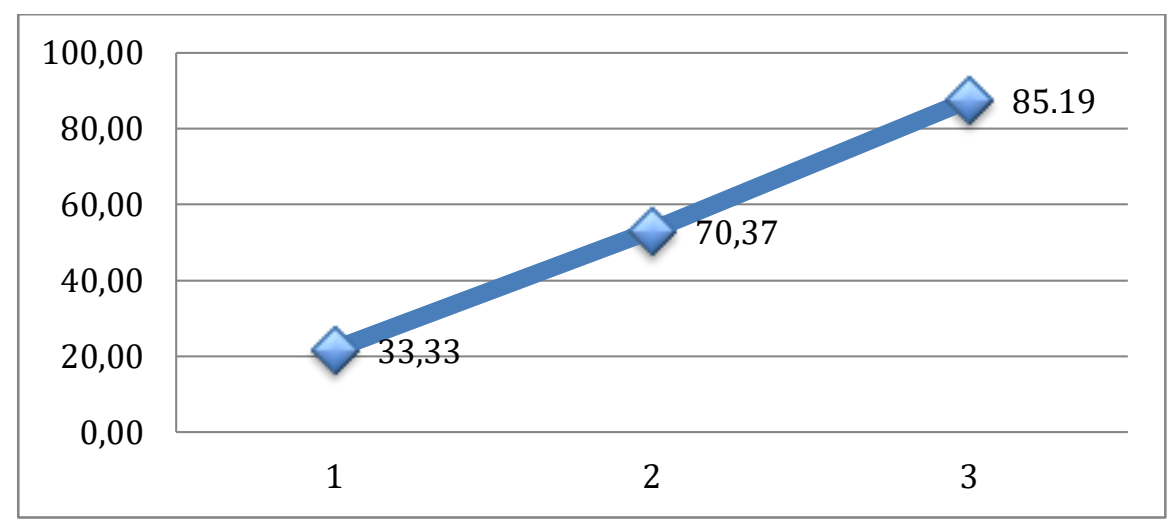

Gambar 1 Pencapaian KKM Klasikal 
Penerapan Model Pembelajaran ....(Hana Rustina)

\section{SIMPULAN}

Berdasarkan hasil kegiatan pembelajaran yang telah dilakukan selama dua siklus, dan berdasarkan seluruh pembahasan serta analisis yang telah dilakukan dapat disimpulkan bahwa metode Demontrasi memiliki dampak positif dalam meningkatkan prestasi belajar siswa yang ditandai dengan peningkatan ketuntasan belajar siswa dalam setiap siklus, yaitu Pra siklus (33,33\%), siklus I (70.37\%), siklus II $(85,19 \%)$. Penerapan metode Demontrasi mempunyai pengaruh positif, yaitu dapat meningkatkan hasil belajar siswa dalam belajar IPA, hal ini ditunjukan dengan antusias siswa yang menyatakan bahwa siswa tertarik dan berminat dengan metode demontrasi sehingga mereka menjadi termotivasi untuk belajar. Metode Demontrasi memiliki dampak positif terhadap kerjasama antara siswa, hal ini ditunjukkan adanya tanggung jawab dalam kelompok dimana siswa yang lebih mampu mengajari temannya yang kurang mampu.

\section{DAFTAR PUSTAKA}

Abdurrahman, M. (2009). Pendidikan Bagi Anak Berkesulitan Belajar. Jakarta: PT. Rineka Cipta

Daryanto. (2009). Panduan Proses Pembelajaran Kreatif dan Inovatif. 2009. Jakarta: AV Publisher.

Depdikbud. (1997). Kamus Besar Bahasa Indonesia. Jakarta: Balai Pustaka

Djamarah, S. B. (2000). Guru dan Anak Didik dalam Interaksi Edukatif. Jakarta: Rineka Cipta.

Hamalik, O. (2012). Kurikulum dan Pembelajaran. Jakarta: Bumi Aksara

Isjoni. (2009). Cooperative Learning. Bandung: Alfabeta.

Kasbolah, K. (1999). Penelitian Tindakan Kelas. Malang: Depdiknas.

Rusman. (2012). Model-Model Pembelajaran Mengembangkan Profesionalisme Guru. Jakarta: PT Raja Grafindo Persada.

Sagala, S. (2010). Konsep dan Makna Pembelajaran. Bandung: Alfabeta

Sanjaya, W. (2006). Strategi Pembelajaran Berorientasi Standar Proses Pendidikan. Jakarta: Kencana Prenada Media Group.

Slameto. (2003). Belajar dan Faktor-Faktor yang Mempengaruhinya. Jakarta: PT. Rineka Cipta.

Haryanto, S. (2012). Pengertian Media Pembelajaran. Yogyakarta: Pustaka. 